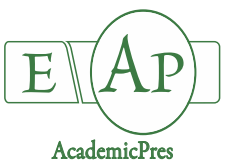

Tuncer B (2020)

Notulae Botanicae Horti Agrobotanici Cluj-Napoca 48(2):814-825

DOI: $10.15835 /$ nbha48211883

Research Article

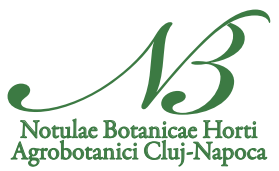

\title{
In vitro germination and bulblet and shoot propagation for wild edible Eremurus spectabilis M.Bieb.
}

\author{
Burcu TUNCER
}

\author{
University of Van Yüzüncü Yal, Faculty of Agriculture, Department of Horticulture, 65080, Van, \\ Turkey; brctuncer@gmail.com ("correspondingauthor)
}

\begin{abstract}
Eremurus spectabilis M.Bieb is consumed as a vegetable because of its nutritious characteristics. The plants are also used for medicinal purposes, in the cut flower industry as an ornamental geophyte, and in industry as a natural adhesive. The aim of the present study was to improve the in vitro propagation protocol for germination and bulblet/shoot formation of E. spectabilis. For this purpose, E. spectabilis seeds were in vitro germinated in four different nutrient media: Murashige and Skoog (MS), Gamborg (B5), White (WH), and Shenk and Hildebrandt (SH). To stimulate bulblet and/or shoot regeneration, hypocotyls of 35-40-day-old in vitro-germinated plantlets were cut into $0.5-1.0 \mathrm{~cm}$ pieces, and the resultant explants were cultured in MS media containing 2,4-dichlorophenoxyacetic acid (2,4-D) $\left(0.5,1.0,2.0\right.$, and $\left.4.0 \mathrm{mg} \mathrm{L}^{-1}\right)+$ kinetin $\left(0.5 \mathrm{mg} \mathrm{L}^{-1}\right)$, thidiazuron (TDZ) $\left(0.5,1.0,2.0\right.$, and $\left.4.0 \mathrm{mg} \mathrm{L}^{-1}\right)+1$-naphthylacetic acid (NAA) $\left(0,0.1,0.5\right.$, and $\left.1.0 \mathrm{mg} \mathrm{L}^{-1}\right)$, and 6-benzylaminopurine (BAP) (0.5, 1.0, 2.0 and $\left.4.0 \mathrm{mg} \mathrm{L}^{-1}\right)+2$,4-dichlorophenoxyacetic acid (2,4-D) (0, $0.1,0.5$, and $\left.1.0 \mathrm{mg} \mathrm{L}^{-1}\right)$. The best outcomes for germination ratio $(57.5 \%)$ were obtained from the $\mathrm{B} 5$ medium. In the third set of in vitro propagation experiments, $100 \%$ bulblet formation was achieved in TDZ $\left(0.5 \mathrm{mg} \mathrm{L}^{-}\right.$ $\left.{ }^{1}\right)$ and NAA (0.5 and $\left.0.1 \mathrm{mg} \mathrm{L}^{-1}\right)$ combinations of MS media, and this was followed by $0.5 \mathrm{mg} \mathrm{L}^{-1}$ BAPcontaining medium (81.3\%). Shoot formation ratios with the same media combinations varied from $60-70 \%$, and the number of shoots per explant varied from 1.4-2.4 shoots. Further in vitro propagation research is planned with larger bulb sizes to develop a protocol for rooting bulblets and/or shoots.
\end{abstract}

Keywords: Eremurus; geophyte; in vitro regeneration; Liliaceae; plant growth; regulator

\section{Introduction}

E. spectabilis M.Bieb., a perennial herbaceous wild species, belongs to the Eremurus genus of the Liliaceae family, which includes about 50 species. Eremurus grows on dry and rocky slopes and is quite widespread, especially in Southern and Central Asia including Iran, Western Pakistan, Turkey, Palestine, Lebanon, Syria and the Caucasus (Wendelbo, 1982; Tuzlac1, 1985; Kamenetsky and Akhmetova, 1994). E. spectabilis has rosette-like, bare (non-hairy) leaves tapering toward the tip (Figure 1a). Plants have shallow roots, and rhizomes are short and bounded to the root bunch (Tuzlac1, 1987). The roots are succulent, juicy, thick, brownish-yellow and fusiform, tapering again toward the tip (Figure 1b). A hermaphrodite, light-yellow flower bunch is located 
over the pedicle. The fruit is green and has three united carpels (Figure 1c). The seeds are 3-4 mm long, trigonal in shape, with sharp edges, narrow wings, and a brownish colour (Figure 1d) (Matthews, 1986).

E. spectabilis is quite rich in antioxidants, phenolics, and minerals and thus, it is a highly nutritious plant (Tosun et al., 2012; Tuzcu et al., 2017). The shoots and leaves are cooked and consumed as vegetables. In addition, different sections of the plant are used for medicinal purposes, especially for the treatment of fungal diseases, diabetes, hepatitis, liver and stomach disorders and some cancers (Baytop, 1999; Tuzlacı and Doğan, 2010; Pourfarzad et al., 2014; Abubaker and Hidayat, 2015; Tuzcu et al., 2017). As well as medical significance, E. spectabilis is also used in cut flower production as a popular ornamental geophyte because of its long and alluring spikes (Schiappacasse et al., 2013; Ahmad et al., 2014). Plant roots are also dried and ground to produce a natural adhesive in industry (Dashti et al., 2005; Heshmatol Vaezin et al., 2010; Eghtedarnejad and Mansouri, 2016).

In vitro regeneration techniques are commonly used for the regeneration of valuable wild species, endangered species, endemic species, and hard-to-regenerate species. Only one study has been conducted on the in vitro regeneration of $E$. spectabilis worldwide (Tuncer, 2017). The researcher cultured E. spectabilis leaf and rhizome explants in BAP (1.0 and $\left.2.0 \mathrm{mg} \mathrm{L}^{-1}\right)$ and 2,4-D (0.5, 1.0, and $\left.2.0 \mathrm{mg} \mathrm{L}^{-1}\right)$ containing MS medium (Murashige and Skoog, 1962). The researcher reported that in vitro shoot regeneration was not achieved in either explant types. In vitro regeneration studies have also been conducted in different species of the Liliaceae family, including the Aloe (Molsaghi et al., 2014; Baskaran et al., 2015; Sharma et al., 2015; Suh et al., 2015; Razib et al., 2016), Lilium (Ault and Siqueira, 2008; Tang et al., 2009; Sun and Jin, 2011), Chlorophytum (Nurashikin et al., 2010; Pandey, 2016), Fritillaria (Çakmak et al., 2016), and Scilla (Kamaleswari et al., 2016) species. In these studies, different in vitro shoot and/or bulblet formation ratios were achieved based on the species and the nutrient media combinations.

The first stage of the protocol to be developed includes in vitro germination, in vitro bulblet and shoot formation. For this purpose, the aim of the present study was to investigate the possibilities of in vitro germination of E. spectabilis seeds in four different nutrient media: Murashige and Skoog(MS), Gamborg (B5), White $(\mathrm{WH})$, and Shenk and Hildebrandt $(\mathrm{SH})$, and in vitro bulblet and/or shoot regeneration from hypocotyl and bulblet explants developed under in vitro conditions with different plant growth regulator (PGR) combinations of MS medium. This study will be the first comprehensive report worldwide about the in vitro propagation of E. spectabilis.
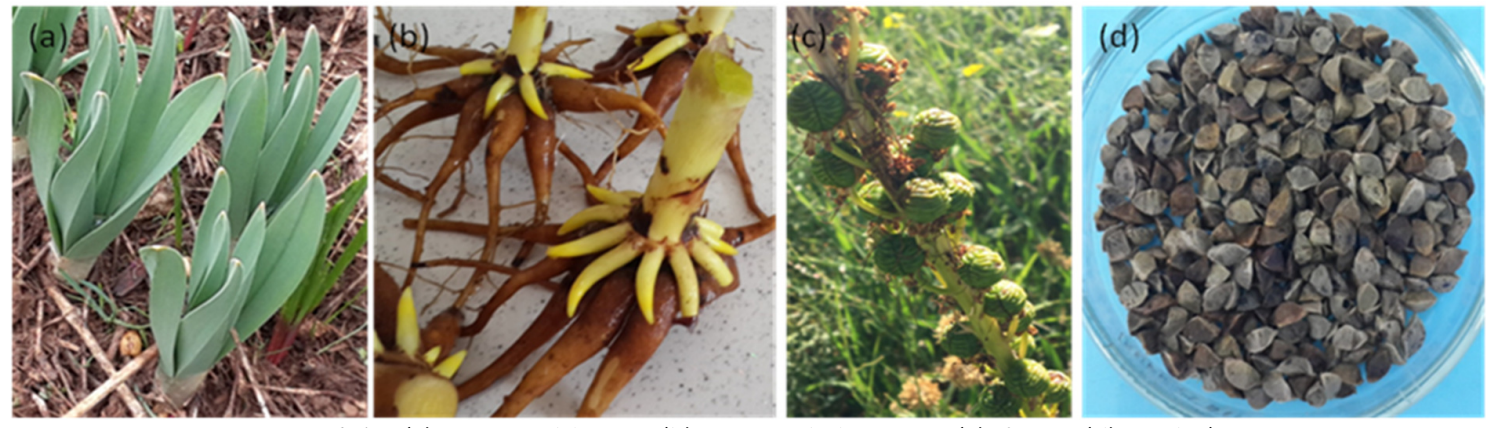

Figure 1. E. spectabilis; (a) stem and leaves, (b) root and rhizomes, (c) fruits, (d) seeds (Tuncer, 2017; Tuncer, 2018) (Photographs: B. Tuncer and K. Keskiner) 


\section{Materials and Methods}

\section{Plant material and sterilization processes}

The E. spectabilis seeds to be used in the experiments were supplied from the Gürpınar ( $38^{\circ} 8^{\prime} 20.75^{\prime \prime} \mathrm{N}$, $43^{\circ} 30^{\prime} 55.15^{\prime \prime} \mathrm{E}, 1730 \mathrm{~m}$ ) in Van province of Turkey in August 2017 (Figure 1d). The seeds were initially kept in $0.3 \%$ benomyl solution for an hour to remove fungal disease agents (Figure 2a), and then shaken and kept in distilled water for an hour. The seeds were then placed into a laminar flow sterile cabin, kept in $40 \%$ sodium hypochlorite $(\mathrm{NaOCl})$ solution containing 1-2 drops of Tween-20 for 10 minutes, and then washed through sterile bidistilled water for five minutes three times (Figure $2 b-c$ ). The surface-sterilized seeds were placed over filter papers to remove excess water. The materials to be used in the germination and regeneration experiments (petri dishes, glass jars, forceps, bistoury, etc.) were sterilized in an autoclave at $121{ }^{\circ} \mathrm{C}$ for 1.5 hours, and the nutrient media were sterilized for 20 minutes.

\section{In vitro germination trials}

Tip-cut seeds were germinated in MS (Murashige and Skoog, 1962), SH (Schenk and Hildebrandt, 1972), B5 (Gamborg et al., 1968), and WH (White, 1943) media under in vitro conditions (Figure 2d-e). All nutrient media were supplemented with $7 \mathrm{~g} \mathrm{~L}^{-1}$ agar, $0.75 \mathrm{~g} \mathrm{~L}^{-1} \mathrm{GA}_{3}$, and $50 \mathrm{mg} \mathrm{L}^{-1}$ citric acid. The $\mathrm{pH}$ of all the media was adjusted to 5.8 (by adding $1 \mathrm{~N} \mathrm{NaOH}$ or $1 \mathrm{~N} \mathrm{HCl}$ ). $20 \mathrm{~g} \mathrm{~L}^{-1}$ of sucrose was added to the $\mathrm{B} 5$ medium, while $30 \mathrm{~g} \mathrm{~L}^{-1}$ of sucrose was added to the MS and SH media. WH media did not contain sucrose. Following seeding, the petri dishes were wrapped in parafilm and preserved in a fridge at $4{ }^{\circ} \mathrm{C}$ until the initiation of germination to break the physiological dormancy of the seeds. Following the initiation of germination, the petri dishes were taken into an incubator set at $13-14{ }^{\circ} \mathrm{C}$ with dark conditions. The emergence of about $2 \mathrm{~mm}$ of radicle from the seed test was considered the criterion for germination (Figure 2e). The following equations were used to calculate the germination parameters (Abdul-Baki and Anderson, 1973; Murillo-Amador et al., 2002; Keskiner and Tuncer, 2019):

Germination ratio $(\%)=(\mathrm{G} / \mathrm{T}) \times 100$

Mean germination time $($ day $)=[(1$.day $G \times 1$. day $)+(2$.day $G \times 2$. day $)+\ldots+($ n.day $G \times$ n.day $)] /$ Total $G$

Germination speed $($ day $)=\mathrm{n} 1 / \mathrm{t} 1+\mathrm{n} 2 / \mathrm{t} 2+\ldots \ldots \ldots . .+\mathrm{nn} / \mathrm{tn}$

$\mathrm{n} 1, \mathrm{n} 2$ : number of germinated seeds, $\mathrm{t} 1, \mathrm{t} 2$ : number of days for germination, $\mathrm{G}$ : germinated seed number; T: total number of seeds
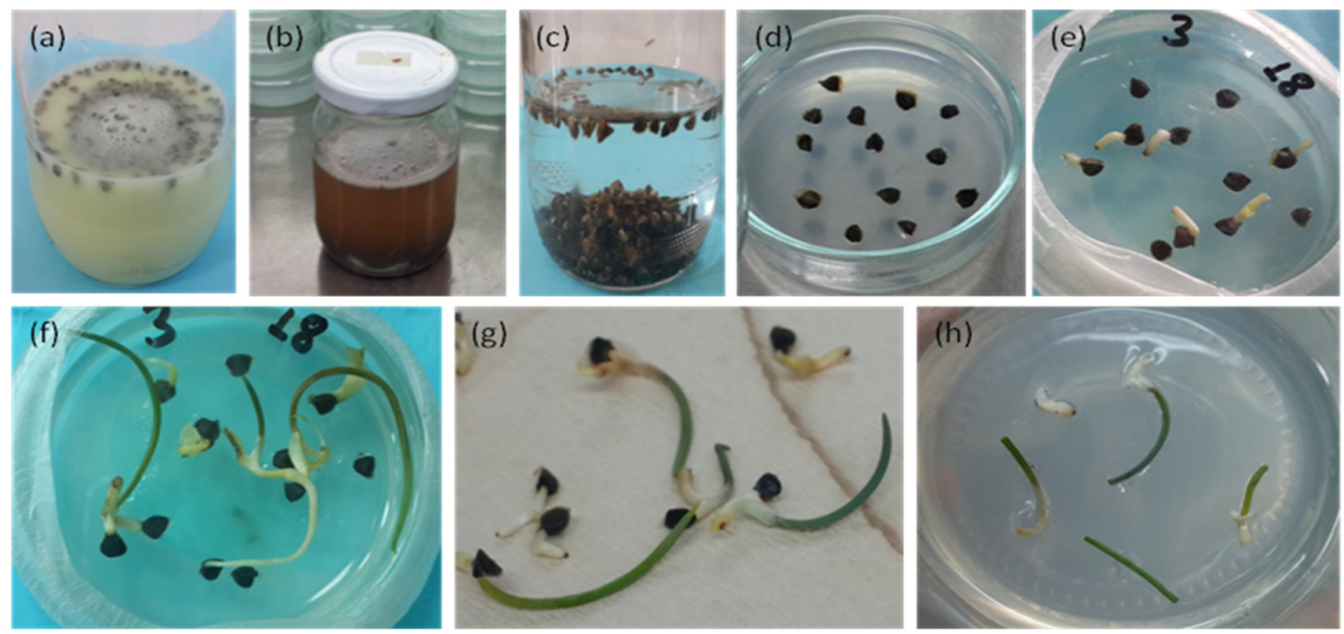

Figure 2. Seeds in (a) $0.3 \%$ benomyl solution, (b) $40 \% \mathrm{NaOCl}$ solution, (c) bidistilled water, (d) in vitro seeding, (e) in vitro germinated seeds, (f-g) hypocotyls developed under in vitro conditions, (h) cultured of hypocotyls explants 


\section{In vitro bulblet and shoot regeneration}

In the first set of experiments, hypocotyl sections of in vitro-germinated seedlings were cut into 0.5-1.0 $\mathrm{cm}$ lengths and used as explants (Figure 2f-h). For in vitro bulblet and shoot formation, explants were cultured in 36 different PGR in combination with MS media containing $30 \mathrm{~g} \mathrm{~L}^{-1}$ sucrose and $7 \mathrm{~g} \mathrm{~L}^{-1}$ agar as well as 2,4$\mathrm{D}\left(0.5,1.0,2.0\right.$, and $\left.4.0 \mathrm{mg} \mathrm{L}^{-1}\right)+$ Kinetin $\left(0.5 \mathrm{mg} \mathrm{L}^{-1}\right)$, TDZ $\left(0.5,1.0,2.0\right.$, and $\left.4.0 \mathrm{mg} \mathrm{L}^{-1}\right)+\mathrm{NAA}(0,0.1,0.5$, and $\left.1.0 \mathrm{mg} \mathrm{L}^{-1}\right)$, or $\operatorname{BAP}\left(0.5,1.0,2.0\right.$, and $\left.4.0 \mathrm{mg} \mathrm{L}^{-1}\right)+2,4-\mathrm{D}\left(0,0.1,0.5\right.$, and $\left.1.0 \mathrm{mg} \mathrm{L}^{-1}\right)$ (Figure $2 \mathrm{~h}$ ).

In the second and third sets of experiments, bulblet segment explants developed under in vitro conditions were used to stimulate bulblet and shoot formation. In the second set of experiments, explants were cultured in 17 PGRs in combination with MS media selected from the first set of experiments. In the third set of experiments, explants were cultured in 9 PGRs combinations selected from the second set of experiments. All the cultures were incubated at $25^{\circ} \mathrm{C} \pm 2{ }^{\circ} \mathrm{C}$ for $16 / 8 \mathrm{~h}$ photoperiod with a light intensity of 3000 lux.

\section{Statistical analysis}

The data were statistically analyzed using analysis of variance (ANOVA) with Statgraphics statistical software, followed by Duncan's multiple range test comparisons for significant differences. The germination experiments were conducted in a completely randomized block design with four replications and five petri dishes (12 seeds/petri dish) in each replication; the in vitro bulblet and shoot regeneration experiments were also set up in a randomized blocks design with three replications with 4-6 explants in the first set of experiments, 5-7 explants in the second set of experiments, and 5-8 explants in the third set of experiments for each replication.

\section{Results}

\section{In vitro germination}

The in vitro germination trial results are summarized in Table 1 . The greatest germination ratio $(57.5 \%)$ and the shortest germination time (3.7 day) were obtained from the B5 medium. The germination ratios of the other nutrient media (MS, WH, and $\mathrm{SH}$ ) varied between 35.0-38.7\%, and mean germination times varied between 4.4-5.7 days; they were placed into the same statistical group (Table 1).

Table 1. Results for in vitro germination of E. spectabilis seeds

\begin{tabular}{|c|c|c|c|}
\hline Media & Germination ratio $(\%)$ & Mean germination time(day) & Germination speed (day) \\
\hline MS & $36.2 \pm 2.1 \mathrm{~b}$ & $5.7 \pm 0.7 \mathrm{a}$ & $1.1 \pm 0.2 \mathrm{c}$ \\
\hline SH & $35.0 \pm 2.8 \mathrm{~b}$ & $5.1 \pm 1.0 \mathrm{ab}$ & $1.4 \pm 0.1 \mathrm{bc}$ \\
\hline B5 & $57.5 \pm 1.7 \mathrm{a}$ & $3.7 \pm 0.6 \mathrm{c}$ & $3.5 \pm 0.9 \mathrm{a}$ \\
\hline WH & $38.7 \pm 2.4 \mathrm{~b}$ & $4.4 \pm 0.8 \mathrm{bc}$ & $1.8 \pm 0.4 \mathrm{~b}$ \\
\hline P Value & $0.001^{* *}$ & $0.003^{* *}$ & $0.000^{* *}$ \\
\hline \multicolumn{2}{|r|}{ The means indicated with different small letters in the same columns are significantly different $\left(\right.$ Duncan test, $\left.{ }^{* *}: \mathrm{p}<0.01\right)$} \\
\hline
\end{tabular}

\section{In vitro bulblet and shoot regeneration}

For in vitro bulblet and shoot regeneration, hypocotyl explants $(0.5-1.0 \mathrm{~cm})$ of 35-40-day old seedlings germinated under in vitro conditions were cultured in 36 different PGR combinations in MS media (Table 2). The statistical analysis showed that there were significant differences among the 36 MS media containing different combinations of PGR $(\mathrm{P}<0.01)$. 
Table 2. In vitro bulblet formation, browning, and swelling ratios of hypocotyl explants of E. spectabilis in PGR combinations in MS media (The first set of experiment)

\begin{tabular}{|c|c|c|c|c|c|}
\hline $\begin{array}{c}\text { Media } \\
\text { No }\end{array}$ & $\begin{array}{c}\text { PGR } \\
\left(\mathrm{mg} \mathrm{L}^{-1}\right)\end{array}$ & $\begin{array}{l}\text { Cultured } \\
\text { explants }\end{array}$ & $\begin{array}{c}\text { Bulblet ratio } \\
(\%) \pm \text { S.E. }\end{array}$ & $\begin{array}{c}\text { Browning ratio } \\
(\%) \pm \text { S.E. }\end{array}$ & $\begin{array}{c}\text { Swelling ratio } \\
(\%) \pm \text { S.E. }\end{array}$ \\
\hline \multicolumn{6}{|c|}{ 2,4-D + Kinetin } \\
\hline 1 & $0.5+0.5$ & 9 & $55.0 \pm 1.1 \mathrm{c}$ & $22.5 \pm 0.5 \mathrm{k}$ & $12.5 \pm 0.5 \mathrm{j}$ \\
\hline 2 & $1.0+0.5$ & 8 & $37.5 \pm 2.5 \mathrm{f}$ & $0.0 \pm 0.0 \ddot{\mathrm{o}}$ & $25.0 \pm 0.41$ \\
\hline 3 & $2.0+0.5$ & 9 & $67.5 \pm 0.5 b$ & $22.5 \pm 0.5 \mathrm{k}$ & $10.0 \pm 0.3 \mathrm{j}$ \\
\hline 4 & $4.0+0.5$ & 10 & $0.0 \pm 0.01$ & $20.8 \pm 0.81$ & $25.0 \pm 0.81$ \\
\hline \multicolumn{6}{|c|}{$\mathrm{TDZ}+\mathrm{NAA}$} \\
\hline 5 & $0.5+0$ & 9 & $45.0 \pm 2.0 \mathrm{~d}$ & $10.0 \pm 0.7 \mathrm{n}$ & $45.0 \pm 2.0 \mathrm{e}$ \\
\hline 6 & $0.5+0.1$ & 8 & $75.0 \pm 2.0 \mathrm{a}$ & $0.0 \pm 0.0$ ö & $25.0 \pm 2.0_{1}$ \\
\hline 7 & $0.5+0.5$ & 11 & $36.6 \pm 0.3 \mathrm{~g}$ & $10.0 \pm 0.5 n$ & $53.3 \pm 2.3 c$ \\
\hline 8 & $0.5+1.0$ & 9 & $40.0 \pm 2.1 \mathrm{ef}$ & $10.0 \pm 0.7 \mathrm{n}$ & $20.0 \pm 0.8 \mathrm{i}$ \\
\hline 9 & $1.0+0$ & 10 & $45.0 \pm 1.0 \mathrm{~d}$ & $20.0 \pm 1.01$ & $40.0 \pm 1.1 \mathrm{f}$ \\
\hline 10 & $1.0+0.1$ & 9 & $36.6 \pm 1.3 \mathrm{~g}$ & $32.5 \pm 0.5 \mathrm{~h}$ & $32.5 \pm 1.5 \mathrm{~g}$ \\
\hline 11 & $1.0+0.5$ & 10 & $41.6 \pm 1.7 \mathrm{e}$ & $29.1 \pm 0.81$ & $29.1 \pm 0.8 \mathrm{~h}$ \\
\hline 12 & $1.0+1.0$ & 9 & $12.5 \pm 0.5 \mathrm{k}$ & $32.5 \pm 1.5 \mathrm{~h}$ & $55.0 \pm 1.0 \mathrm{c}$ \\
\hline 13 & $2.0+0$ & 8 & $12.5 \pm 0.5 \mathrm{k}$ & $62.5 \pm 0.5 c$ & $25.0 \pm 1.01$ \\
\hline 14 & $2.0+0.1$ & 8 & $30.0 \pm 0.5 \mathrm{~h}$ & $50.0 \pm 0.3 \mathrm{~d}$ & $25.0 \pm 0.41$ \\
\hline 15 & $2.0+0.5$ & 9 & $75.0 \pm 1.4 \mathrm{a}$ & $12.5 \pm 0.5 \mathrm{~m}$ & $25.0 \pm 2.01$ \\
\hline 16 & $2.0+1.0$ & 9 & $37.5 \pm 0.5 \mathrm{f}$ & $42.5 \pm 0.9 \mathrm{e}$ & $12.5 \pm 1.5 \mathrm{j}$ \\
\hline 17 & $4.0+0$ & 10 & $70.0 \pm 2.0 \mathrm{~b}$ & $20.0 \pm 0.31$ & $0.0 \pm 0.0 \mathrm{k}$ \\
\hline 18 & $4.0+0.1$ & 9 & $12.5 \pm 1.5 \mathrm{k}$ & $0.0 \pm 0.0 \ddot{~}$ & $45.0 \pm 1.0 \mathrm{e}$ \\
\hline 19 & $4.0+0.5$ & 11 & $25.0 \pm 0.81$ & $26.6 \pm 1.7 \mathrm{i}$ & $10.0 \pm 0.3 \mathrm{j}$ \\
\hline 20 & $4.0+1.0$ & 8 & $25.0 \pm 0.71$ & $25.0 \pm 0.5 \mathrm{j}$ & $12.5 \pm 0.5 \mathrm{j}$ \\
\hline \multicolumn{6}{|c|}{$\mathrm{BAP}+2,4-\mathrm{D}$} \\
\hline 21 & $0.5+0$ & 9 & $37.5 \pm 0.5 \mathrm{f}$ & $20.0 \pm 0.71$ & $55.0 \pm 1.0 \mathrm{c}$ \\
\hline 22 & $0.5+0.1$ & 9 & $0.0 \pm 0.01$ & $22.5 \pm 0.5 \mathrm{k}$ & $65.0 \pm 1.0 \mathrm{~b}$ \\
\hline 23 & $0.5+0.5$ & 9 & $10.0 \pm 0.1 \mathrm{k}$ & $40.0 \pm 1.1 \mathrm{f}$ & $25.0 \pm 0.31$ \\
\hline 24 & $0.5+1.0$ & 11 & $22.5 \pm 0.5 \mathrm{ii}$ & $35.0 \pm 0.9 \mathrm{~g}$ & $0.0 \pm 0.0 \mathrm{k}$ \\
\hline 25 & $1.0+0$ & 10 & $12.5 \pm 0.5 \mathrm{k}$ & $50.0 \pm 1.3 \mathrm{~d}$ & $70.8 \pm 1.2 \mathrm{a}$ \\
\hline 26 & $1.0+0.1$ & 8 & $25.0 \pm 0.61$ & $25.0 \pm 0.7 \mathrm{j}$ & $50.0 \pm 1.0 \mathrm{~d}$ \\
\hline 27 & $1.0+0.5$ & 8 & $25.0 \pm 0.91$ & $25.0 \pm 0.8 \mathrm{j}$ & $25.0 \pm 0.61$ \\
\hline 28 & $1.0+1.0$ & 8 & $12.5 \pm 0.5 \mathrm{k}$ & $75.0 \pm 1.2 \mathrm{~b}$ & $0.0 \pm 0.0 \mathrm{k}$ \\
\hline 29 & $2.0+0$ & 9 & $0.0 \pm 0.01$ & $40.0 \pm 0.9 \mathrm{f}$ & $12.5 \pm 0.5 \mathrm{j}$ \\
\hline 30 & $2.0+0.1$ & 12 & $25.0 \pm 1.71$ & $42.5 \pm 0.5 \mathrm{e}$ & $28.3 \pm 0.7 \mathrm{~h}$ \\
\hline 31 & $2.0+0.5$ & 11 & $0.0 \pm 0.01$ & $33.3 \pm 1.3 \mathrm{~h}$ & $18.3 \pm 0.7 \mathrm{i}$ \\
\hline 32 & $2.0+1.0$ & 9 & $20.0 \pm 0.4 \mathrm{i}$ & $10.0 \pm 0.3 n$ & $12.5 \pm 0.5 \mathrm{j}$ \\
\hline 33 & $4.0+0$ & 11 & $16.6 \pm 1.7 \mathrm{j}$ & $10.0 \pm 0.3 n$ & $46.6 \pm 0.3 \mathrm{e}$ \\
\hline 34 & $4.0+0.1$ & 7 & $16.6 \pm 0.7 j$ & $25.0 \pm 0.9 j$ & $12.5 \pm 0.5 \mathrm{j}$ \\
\hline 35 & $4.0+0.5$ & 8 & $0.0 \pm 0.01$ & $87.5 \pm 0.5 \mathrm{a}$ & $12.5 \pm 0.5 \mathrm{j}$ \\
\hline 36 & $4.0+1.0$ & 8 & $25.0 \pm 0.81$ & $0.0 \pm 0.0 \ddot{o}$ & $37.5 \pm 0.5 \mathrm{f}$ \\
\hline \multicolumn{3}{|c|}{ P Value } & $0.000^{* *}$ & $0.000^{* *}$ & $0.000^{* *}$ \\
\hline
\end{tabular}

The means indicated with different small letters in the same columns are significantly different (Duncan test, ${ }^{* *}: \mathrm{p}<0.01$ )

Bulblet formation ratios (\%) in MS media varied between $0.0-75.0 \%$ based on PGR combinations. The best outcomes for bulblet formation ratios were obtained, respectively, from the $6^{\text {th }}\left(0.5 \mathrm{mg} \mathrm{L}^{-1} \mathrm{TDZ}+0.1 \mathrm{mg}\right.$ $\left.\mathrm{L}^{-1} \mathrm{NAA}\right)$ medium $(75 \%)$, the $15^{\text {th }}\left(2 \mathrm{mg} \mathrm{L}^{-1} \mathrm{TDZ}+0.5 \mathrm{mg} \mathrm{L}^{-1} \mathrm{NAA}\right)$ medium $(75 \%)$, the $17^{\text {th }}\left(4 \mathrm{mg} \mathrm{L}^{-1} \mathrm{TDZ}\right)$ medium (70\%), and the $3^{\text {rd }}\left(2 \mathrm{mg} \mathrm{L}^{-1} 2,4-\mathrm{D}+0.5 \mathrm{mg} \mathrm{L}^{-1} \mathrm{Kin}\right)$ medium (67.5\%) (Table 2). In general, in MS media, lower bulblet formation ratios $(\%)$ and greater browning ratios (\%) were observed in BAP $+2,4-\mathrm{D}$ 
combinations than in the other PGR combinations. The greatest browning ratios of planted explants were observed in the $35^{\text {th }}\left(4 \mathrm{mg} \mathrm{L}^{-1} \mathrm{BAP}+0.5 \mathrm{mg} \mathrm{L}^{-1} 2,4-\mathrm{D}\right)$ and $28^{\text {th }}\left(1 \mathrm{mg} \mathrm{L}^{-1} \mathrm{BAP}+1 \mathrm{mg} \mathrm{L}^{-1} 2,4-\mathrm{D}\right)$ media (Table 2). The lowest bulblet formation ratios or no bulblet formation along with, the greatest swelling ratios (\%) were observed, respectively, in the $25^{\text {th }}$ medium $\left(1 \mathrm{mg} \mathrm{L}^{-1} \mathrm{BAP}\right)(70.8 \%)$ and the $22^{\text {nd }}$ medium $\left(0.5 \mathrm{mg} \mathrm{L}^{-1} \mathrm{BAP}+0.1\right.$ $\left.\mathrm{mg} \mathrm{L}^{-1} 2,4-\mathrm{D}\right)(65 \%)$. In the first set of experiments, direct bulblet formation was provided from the hypocotyl explants planted into 36 PGR combinations in MS media (Table 2).

According to the results of the first set of experiments, 17 PGR combinations in MS media with more successful outcomes were selected (Table 3), and the second set of experiments were set up (35-40 days after the first set of experiments).

Table 3. Bulblet and shoot formation of in vitro-developed bulblet explants of E. spectabilis (The second set of experiment)

\begin{tabular}{|c|c|c|c|c|c|c|}
\hline $\begin{array}{c}\text { Media } \\
\text { No }\end{array}$ & $\begin{array}{c}\text { PGR } \\
\left(\mathrm{mg} \mathrm{L}^{-1}\right)\end{array}$ & $\begin{array}{l}\text { Cultured } \\
\text { explants }\end{array}$ & $\begin{array}{c}\text { Bulblet ratio } \\
(\%) \pm \text { S.E. }\end{array}$ & $\begin{array}{c}\text { Browning ratio } \\
(\%) \pm \text { S.E. }\end{array}$ & $\begin{array}{c}\text { Shoot ratio } \\
(\%) \pm \text { S.E. }\end{array}$ & $\begin{array}{c}\text { Shoot/explant } \\
\pm \text { S.E. }\end{array}$ \\
\hline \multicolumn{7}{|c|}{ 2,4-D + Kinetin } \\
\hline 1 & $0.5+0.5$ & 12 & $41.6 \pm 1.3 \mathrm{~g}$ & $0.0 \pm 0.0 \mathrm{~d}$ & $16.6 \pm 0.5 \mathrm{i}$ & $0.5 \pm 0.1 \mathrm{~g}$ \\
\hline 2 & $1.0+0.5$ & 12 & $41.6 \pm 1.3 \mathrm{~g}$ & $0.0 \pm 0.0 \mathrm{~d}$ & $24.9 \pm 1.3 \mathrm{~h}$ & $0.5 \pm 0.1 \mathrm{~g}$ \\
\hline 3 & $2.0+0.5$ & 13 & $45.0 \pm 0.9 \mathrm{f}$ & $38.7 \pm 1.3 \mathrm{a}$ & $16.2 \pm 1.2 \mathrm{i}$ & $0.7 \pm 0.1 \mathrm{e}$ \\
\hline \multicolumn{7}{|c|}{$\mathrm{TDZ}+\mathrm{NAA}$} \\
\hline 5 & $0.5+0$ & 10 & $30.0 \pm 2.0 \mathrm{i}$ & $0.0 \pm 0.0 \mathrm{~d}$ & $10.0 \pm 0.3 \mathrm{j}$ & $0.4 \pm 0.1 \mathrm{~h}$ \\
\hline 6 & $0.5+0.1$ & 13 & $61.9 \pm 1.8 \mathrm{c}$ & $0.0 \pm 0.0 \mathrm{~d}$ & $46.4 \pm 0.6 \mathrm{f}$ & $1.0 \pm 0.3 \mathrm{bc}$ \\
\hline 7 & $0.5+0.5$ & 11 & $81.6 \pm 1.7 \mathrm{a}$ & $0.0 \pm 0.0 \mathrm{~d}$ & $63.3 \pm 0.3 b$ & $1.0 \pm 0.3 \mathrm{bc}$ \\
\hline 8 & $0.5+1.0$ & 14 & $49.9 \pm 0.9 \mathrm{e}$ & $0.0 \pm 0.0 \mathrm{~d}$ & $49.9 \pm 0.1 \mathrm{e}$ & $0.9 \pm 0.1 \mathrm{c}$ \\
\hline 9 & $1.0+0$ & 12 & $58.3 \pm 1.3 \mathrm{~d}$ & $0.0 \pm 0.0 \mathrm{~d}$ & $28.3 \pm 0.7 \mathrm{~g}$ & $0.8 \pm 0.2 \mathrm{~d}$ \\
\hline 10 & $1.0+0.1$ & 12 & $60.0 \pm 1.5 \mathrm{~cd}$ & $0.0 \pm 0.0 \mathrm{~d}$ & $28.3 \pm 0.3 \mathrm{~g}$ & $0.8 \pm 0.2 \mathrm{~d}$ \\
\hline 11 & $1.0+0.5$ & 12 & $33.3 \pm 0.91$ & $0.0 \pm 0.0 \mathrm{~d}$ & $16.6 \pm 0.7 \mathrm{i}$ & $0.6 \pm 0.1 \mathrm{f}$ \\
\hline 14 & $2.0+0.1$ & 12 & $75.7 \pm 0.7 \mathrm{~b}$ & $0.0 \pm 0.0 \mathrm{~d}$ & $51.4 \pm 1.4 \mathrm{~d}$ & $0.9 \pm 0.1 \mathrm{c}$ \\
\hline 15 & $2.0+0.5$ & 11 & $36.6 \pm 1.3 \mathrm{~h}$ & $0.0 \pm 0.0 \mathrm{~d}$ & $5.5 \pm 0.4 \mathrm{k}$ & $0.4 \pm 0.1 \mathrm{~h}$ \\
\hline 16 & $2.0+1.0$ & 11 & $28.3 \pm 0.7 \mathrm{i}$ & $8.3 \pm 0.3 \mathrm{~b}$ & $16.6 \pm 1.7 \mathrm{i}$ & $0.5 \pm 0.1 \mathrm{~g}$ \\
\hline 17 & $4.0+0$ & 12 & $75.7 \pm 0.7 b$ & $7.1 \pm 0.1 \mathrm{c}$ & $48.5 \pm 0.6 \mathrm{e}$ & $1.1 \pm 0.2 \mathrm{~b}$ \\
\hline 19 & $4.0+0.5$ & 10 & $20.0 \pm 0.5 \mathrm{j}$ & $0.0 \pm 0.0 \mathrm{~d}$ & $20.0 \pm 0.71$ & $0.4 \pm 0.1 \mathrm{~h}$ \\
\hline 20 & $4.0+1.0$ & 12 & $49.9 \pm 0.7 \mathrm{e}$ & $0.0 \pm 0.0 \mathrm{~d}$ & $58.3 \pm 0.3 c$ & $1.0 \pm 0.5 \mathrm{bc}$ \\
\hline \multicolumn{7}{|c|}{$\mathrm{BAP}+2,4-\mathrm{D}$} \\
\hline 21 & $0.5+0$ & 12 & $83.3 \pm 1.4 \mathrm{a}$ & $0.0 \pm 0.0 \mathrm{~d}$ & $83.3 \pm 1.3 \mathrm{a}$ & $1.3 \pm 0.4 \mathrm{a}$ \\
\hline \multicolumn{3}{|c|}{ P Value } & $0.000^{* *}$ & $0.000^{* *}$ & $0.000^{* *}$ & $0.000^{* *}$ \\
\hline
\end{tabular}

The means indicated with different small letters in the same columns are significantly different (Duncan test, ${ }^{* *}: \mathrm{p}<0.01$ )

Bulblet pieces developed under in vitro conditions were used as explants. The differences in the investigated parameters of the 17 PGR combinations in MS media were found to be significant $(p<0.01)$. The best outcomes in terms of bulblet formation ratios were obtained, respectively, from the $21^{\text {st }}\left(0.5 \mathrm{mg} \mathrm{L}^{-1} \mathrm{BAP}\right)$ (83.3\%), the $7^{\text {th }}\left(0.5 \mathrm{mg} \mathrm{L}^{-1} \mathrm{TDZ}+0.5 \mathrm{mg} \mathrm{L}^{-1} \mathrm{NAA}\right)(81.6 \%)$, the $14^{\text {th }}\left(2 \mathrm{mg} \mathrm{L}^{-1} \mathrm{TDZ}+0.1 \mathrm{mg} \mathrm{L}^{-1} \mathrm{NAA}\right)$ (75.7\%), and the $17^{\text {th }}\left(4 \mathrm{mg} \mathrm{L}^{-1} \mathrm{TDZ}\right)(75.7 \%)$ media. Except for a few media, $\left(3^{\text {rd }}, 16^{\text {th }}\right.$, and $17^{\text {th }}$ media), browning was not observed in the explants (Table 3). In terms of shoot formation ratios, the $21^{\text {st }}\left(0.5 \mathrm{mg} \mathrm{L}^{-1}\right.$ BAP) (83.3\%) and the $7^{\text {th }}\left(0.5 \mathrm{mg} \mathrm{L}^{-1} \mathrm{TDZ}+0.5 \mathrm{mg} \mathrm{L}^{-1} \mathrm{NAA}\right)$ media $(63.3 \%)$ were the most successful. The greatest number of shoots per explant was obtained from the $21^{\text {st }}$ and the $17^{\text {th }}$ media, and they were followed by the $20^{\text {th }}\left(4 \mathrm{mg} \mathrm{L}^{-1} \mathrm{TDZ}+1 \mathrm{mg} \mathrm{L}^{-1} \mathrm{NAA}\right)$, the $6^{\text {th }}\left(0.5 \mathrm{mg} \mathrm{L}^{-1} \mathrm{TDZ}+0.1 \mathrm{mg} \mathrm{L}^{-1} \mathrm{NAA}\right)$, and the $7^{\text {th }}(0.5 \mathrm{mg} \mathrm{L}$ ${ }^{1} \mathrm{TDZ}+0.5 \mathrm{mg} \mathrm{L}^{-1} \mathrm{NAA}$ ) media, which were placed into the same statistical group (Table 3 ).

For the third set of experiments, 9 PGR combinations with better outcomes in terms of bulblet and shoot formation were selected. Bulblet pieces developed under in vitro conditions were used as explants, and the resulting data are provided in Table 4 . In the third set of experiments, a $100 \%$ bulblet formation ratio was 
achieved in TDZ (0.5 mg L $\left.\mathrm{m}^{-1}\right)$ and NAA (0.5 and $\left.1.0 \mathrm{mg} \mathrm{L}^{-1}\right)$ combinations of MS media. These PGR combinations were followed by the MS medium containing only $0.5 \mathrm{mg} \mathrm{L}^{-1} \mathrm{BAP}(81.3 \%)$ (Table 4). The shoot formation ratios of PGR combinations varied from 10.0-70.0\%, and the number of shoots per explant varied from 0.5-2.4 shoots. The greatest shoot formation ratio (70\%) was obtained from the MS medium containing $0.5 \mathrm{mg} \mathrm{L}^{-1} \mathrm{TDZ}$ and $1.0 \mathrm{mg} \mathrm{L}^{-1} \mathrm{NAA}$ and the greatest number of shoots per explant (2.4 shoots) was obtained from the MS medium containing $0.5 \mathrm{mg} \mathrm{L}^{-1} \mathrm{TDZ}$ and $0.5 \mathrm{mg} \mathrm{L}^{-1} \mathrm{NAA}$ (Table 4). Figure 3 presents the in vitro bulblet and shoot regeneration in different PGR combinations of MS media.

Table 4. Bulblet and shoot formation of in vitro-developed bulblet explants of E. spectabilis (The third set of experiment)

\begin{tabular}{|c|c|c|c|c|c|}
\hline Media No & $\begin{array}{c}\text { PGR } \\
\left(\mathrm{mg} \mathrm{L}^{-1}\right)\end{array}$ & $\begin{array}{l}\text { Cultured } \\
\text { explants }\end{array}$ & $\begin{array}{l}\text { Bulblet ratio (\%) } \\
\quad \pm \text { S.E. }\end{array}$ & $\begin{array}{l}\text { Shoot ratio } \\
(\%) \pm \text { S.E. }\end{array}$ & Shoot/explant \pm S.E. \\
\hline \multicolumn{6}{|c|}{$\mathrm{TDZ}+\mathrm{NAA}$} \\
\hline 6 & $0.5+0.1$ & 11 & $63.3 \pm 1.3 \mathrm{c}$ & $28.3 \pm 0.3 \mathrm{e}$ & $1.0 \pm 0.1 \mathrm{~b}-\mathrm{d}$ \\
\hline 7 & $0.5+0.5$ & 11 & $100.0 \pm 2.2 \mathrm{a}$ & $60.0 \pm 1.0 \mathrm{~b}$ & $2.4 \pm 0.2 \mathrm{a}$ \\
\hline 8 & $0.5+1.0$ & 10 & $100.0 \pm 1.9 \mathrm{a}$ & $70.0 \pm 2.0 \mathrm{a}$ & $1.5 \pm 0.5 \mathrm{a}-\mathrm{c}$ \\
\hline 9 & $1.0+0$ & 10 & $60.0 \pm 1.3 \mathrm{~d}$ & $10.0 \pm 0.8 \mathrm{~g}$ & $0.5 \pm 0.5 \mathrm{~d}$ \\
\hline 10 & $1.0+0.1$ & 11 & $35.0 \pm 2.0 \mathrm{~g}$ & $16.6 \pm 1.7 \mathrm{f}$ & $0.6 \pm 0.3 \mathrm{~cd}$ \\
\hline 14 & $2.0+0.1$ & 18 & $55.5 \pm 1.4 \mathrm{e}$ & $33.3 \pm 1.1 \mathrm{~d}$ & $0.6 \pm 0.2 \mathrm{~cd}$ \\
\hline 17 & $4.0+0$ & 18 & $38.9 \pm 0.6 \mathrm{f}$ & $16.6 \pm 0.5 \mathrm{f}$ & $0.5 \pm 0.1 \mathrm{~d}$ \\
\hline 20 & $4.0+1.0$ & 15 & $66.1 \pm 1.1 \mathrm{c}$ & $47.3 \pm 0.8 \mathrm{c}$ & $1.7 \pm 0.2 \mathrm{ab}$ \\
\hline \multicolumn{6}{|c|}{$\mathrm{BAP}+2,4-\mathrm{D}$} \\
\hline 21 & $0.5+0$ & 16 & $81.3 \pm 1.3 \mathrm{~b}$ & $62.5 \pm 0.5 b$ & $1.4 \pm 0.3 \mathrm{a}-\mathrm{d}$ \\
\hline \multicolumn{2}{|c|}{ P Value } & & $0.000^{* *}$ & $0.000^{* *}$ & $0.016^{*}$ \\
\hline
\end{tabular}

The means indicated with different small letters in the same columns are significantly different (Duncan test, ${ }^{* *}: \mathrm{p}<$ $\left.0.01,{ }^{*}: \mathrm{p}<0.05\right)$
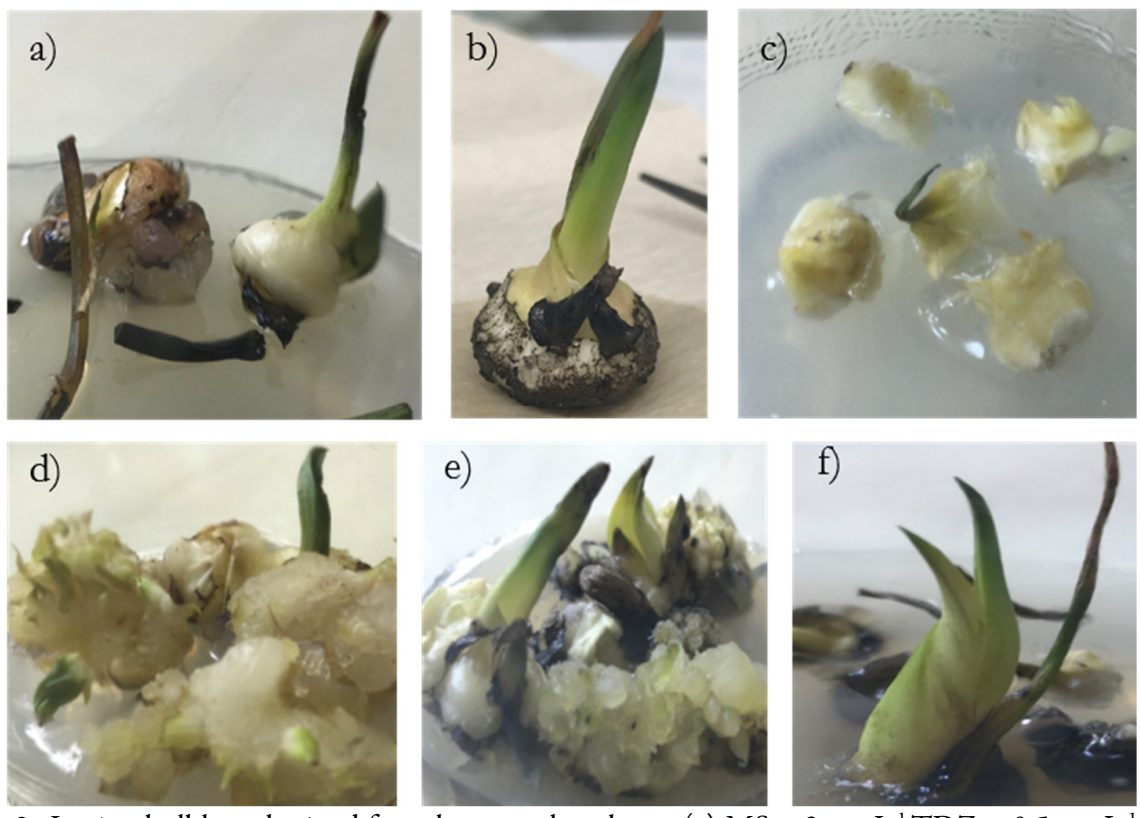

Figure 3. In vitro bulblets obtained from hypocotyl explants; (a) $\mathrm{MS}+2 \mathrm{mg} \mathrm{L}^{-1} \mathrm{TDZ}+0.5 \mathrm{mg} \mathrm{L}^{-1} \mathrm{NAA}$, (b) $\mathrm{MS}+0.5 \mathrm{mg} \mathrm{L} \mathrm{L}^{-1} \mathrm{TDZ}+0.1 \mathrm{mg} \mathrm{L}^{-1} \mathrm{NAA}$, (c) cut into pieces and plantation of in vitro-developed bulblets into nutrient media, (d-e) MS $+0.5 \mathrm{mg} \mathrm{L}^{-1} \mathrm{TDZ}+0.5 \mathrm{mg} \mathrm{L}^{-1} \mathrm{NAA}$, (f) MS $+0.5 \mathrm{mg} \mathrm{L}^{-1} \mathrm{BAP}$ 


\section{Discussion}

There are only two studies about in vitro germination of E. spectabilis; these were conducted by Keskiner (2017) and Akdağ (2019). Keskiner (2017) germinated 1,500 ppm GA G $_{3}$-supplemented and unsupplemented E. spectabilis seeds in three different nutrient media (MS, WH, and B5) and reported quite low germination ratios (0.83\%-1.50\%) only in the WH medium. Akdağ (2019) germinated E. spectabilis seeds in three different nutrient media (MS, WH, and B5) under in vitro conditions, preserved the seeded petri dishes in a fridge (4 ${ }^{\circ} \mathrm{C}$ ) for different durations (30, 50, 80, and 100 days), and reported the greatest germination ratio (5.88\%) for 100-day cold storage with MS medium. However, it is remarkable that both Keskiner (2017) and Akdağ (2019) reported quite low germination ratios under in vitro conditions.

Other studies (not under in vitro conditions) have investigated the germination of E. spectabilis. Rahmanpour et al. (2005) subjected E. spectabilis seeds to mechanical abrasion followed by immersion into $0.01 \mathrm{M} \mathrm{GA}_{3}$ solution for 45 minutes and reported a 53\% germination ratio. Güngör (2002) reported the greatest germination ratio $(65.3 \%)$ for 90 -day moist-cold stratification treatments, and Keskiner and Tuncer (2019) reported the greatest germination ratio (73.3\%) for 100-day moist-cold stratification treatments. Despite the high germination ratios, quite long moist-cold stratification durations ( 90 and 100 days) were used, and long mean germination times were observed in those studies. Akdağ (2019) cut the tips of E. spectabilis seeds, subjected them to moist-cold stratification treatments for different durations $(30,50,80$, and 100 days) and reported germination ratios from 45.4-60.6\%; high germination ratios were achieved even with a short duration (< 30 days) of moist-cold stratification treatments of the tip-cut seeds. Akdağs (2019) results were taken into consideration in this study, and thus the in vitro germination experiments were set up with tip-cut E. spectabilis seeds. Therefore, the present findings comply with the results of Akdağ (2019).

In previous studies conducted with other species of the Eremurus genus under non-in vitro conditions, Rahmanpour et al. (2007) reported the greatest germination ratio (80\%) and germination speed (1.6 day) of $E$. olgae for seeds immersed in water for 24-48 hours, tip cut, seed testa abraded, and immersed into a $0.08 \mathrm{M} \mathrm{GA}_{3}$ solution for 45 minutes; it was reported that tip cutting and abrasion of seed testa improved germination ratios and shortened mean germination times in E. spectabilis (Rahmanpour et al., 2005; Akdağ, 2019), in E. olgae (Rahmanpour et al., 2007). Present findings comply with the results of Rahmanpour et al. (2005), Rahmanpour et al. (2007) and Akdağ (2019). Sufficient germination ratios were achieved from tip-cut seeds preserved in a fridge $\left(4{ }^{\circ} \mathrm{C}\right)$ for short durations $(<30$ days $)$ under in vitro conditions.

Only one study worldwide has investigated the in vitro propagation of E. spectabilis. Tuncer (2017) cultured leaf and rhizome explants of E. spectabilis in BAP $\left(1.0\right.$ and $\left.2.0 \mathrm{mg} \mathrm{L}^{-1}\right)$ and 2,4-D (0.5, 1.0, and $2.0 \mathrm{mg}$ $\left.\mathrm{L}^{-1}\right)$ combinations of MS media, but was not able to achieve any bulblet and shoot formations. In the present study, several different PGR combinations were experimented with in MS media, and sterile hypocotyl and bulblet explants obtained under in vitro conditions were used; thus, the findings of the present study were quite successful compared with Tuncer (2017). In the first set of experiments, in vitro direct bulblet formation was achieved from the hypocotyl explants; in the second and third set of experiments, both bulblet and shoot formations were achieved from bulblet segments developed under in vitro conditions with different PGR combinations on MS medium. In the third set of experiments, a bulblet formation ratio of $81.3-100 \%$ was achieved with TDZ $\left(0.5 \mathrm{mg} \mathrm{L}^{-1}\right)+\mathrm{NAA}\left(0.5\right.$ and $\left.1.0 \mathrm{mg} \mathrm{L}^{-1}\right)$ combinations and $0.5 \mathrm{mg} \mathrm{L}^{-1} \mathrm{BAP}$-containing MS media; shoot formation ratios of $60-70 \%$ were also achieved with the same nutrient media combinations (Table 4).

Different researchers have used different cytokinin and/or auxin group hormones at different ratios for in vitro bulblet and shoot regeneration in species of the Liliaceae family. Nurashikin et al. (2010) obtained the greatest shoot regeneration (18.9 shoots/explant) from young shoot explants of Chlorophytum borivilianum from $3 \mathrm{mg} \mathrm{L}^{-1} \mathrm{BAP}$-supplemented MS medium. Choudhary et al. (2011) obtained the greatest shoot formation 
ratio of shoot tip explants of Aloe vera from BAP $\left(1.0 \mathrm{mg} \mathrm{L}^{-1}\right)+\mathrm{NAA}\left(0.5 \mathrm{mg} \mathrm{L}^{-1}\right)$ combination of MS medium. Razib et al. (2016) reported about $90 \%$ shoot regeneration from $2.0 \mathrm{mg} \mathrm{L}^{-1} \mathrm{BA}+0.5 \mathrm{mg} \mathrm{L}^{-1} \mathrm{NAA}+40.0 \mathrm{mg} \mathrm{L}$ ${ }^{1}$ Ads (Adenine sulfide)-supplemented MS medium. Molsaghi et al. (2014) indicated successful outcomes for shoot regeneration with $\mathrm{MS}+1 \mathrm{mg} \mathrm{L}^{-1} \mathrm{IAA}+4 \mathrm{mg} \mathrm{L}^{-1} \mathrm{BAP}(58.88 \%)$ and from $\mathrm{MS}+0.2 \mathrm{mg} \mathrm{L}^{-1} \mathrm{IAA}+0.8$ $\mathrm{mg} \mathrm{L}^{-1} \mathrm{BAP}$ media (48.03\%).

Jakhar et al. (2012) obtained the maximum shoot regeneration of micro shoots of Aloe barbadensis Mill. with young leaves with $0.5 \mathrm{mg} \mathrm{L}^{-1} \mathrm{BAP}$-containing medium; Baskaran et al. (2015) obtained 15.4 shoots per explant from shoot tip and leaf explants of the medicinal plant Aloe pruinosa in MS $+5 \mu \mathrm{M} \mathrm{BA}+4 \mu \mathrm{M}$ IAA medium; Kamaleswari et al. (2016) reported the maximum number of shoots per explant of leaf explants of Scilla hyacinthina with $2 \mathrm{mg} \mathrm{L}^{-1} \mathrm{BAP}-$ supplemented media. Pandey (2016) was able to achieve maximum shoot regeneration of stem explants of bulbous Chlorophytum borivilianum from the MS media containing only $5 \mathrm{mg}$ $\mathrm{L}^{-1} \mathrm{BAP}$. Tang et al. (2009) cultured leaf explants of Lilium longiflorum in MS + BAP $\left(0.1 \mathrm{mg} \mathrm{L}^{-1}\right)+\mathrm{NAA}(0.5$ and $\left.2.0 \mathrm{mg} \mathrm{L}^{-1}\right)$ media and reported direct bulblet formation in all media combinations. Complying with the results of Tang et al. (2009), in the first set of my experiments, direct bulblet formation was achieved from hypocotyl explants at varying ratios (0.0-75.0\%) based on PGR combinations (Table 2). In the first set of experiments, greater bulblet formation ratios (\%) were obtained from 2,4-D $\left(0.5,1.0\right.$, and $\left.2.0 \mathrm{mg} \mathrm{L}^{-1}\right)+$ Kinetin $\left(0.5 \mathrm{mg} \mathrm{L}^{-1}\right), \mathrm{TDZ}+\mathrm{NAA}$ combinations, and only $0.5 \mathrm{mg} \mathrm{L}^{-1} \mathrm{BAP}$-containing PGR combinations of MS media than from the other PGR combinations (Table 2).

In vitro bulblet and/or shoot formations were also reported in previous studies in which bulblet segments were used as explants. Haibin and Jiajun (2006) reported the greatest shoot regeneration of Lilium lancifolium in $\mathrm{MS}+\mathrm{BA}\left(1.5 \mathrm{mg} \mathrm{L}^{-1}\right)+\mathrm{NAA}\left(0.2 \mathrm{mg} \mathrm{L}^{-1}\right)$ media. Yang et al. (2010) reported the greatest shoot regeneration of $L$. tsingtauense in $\mathrm{MS}+0.1 \mathrm{mg} \mathrm{L}^{-1} \mathrm{NAA}+2.0 \mathrm{mg} \mathrm{L}^{-1} \mathrm{BA}$ combination. Sun and Jin (2011) reported the greatest shoot regeneration of $L$. longiflorum in $\mathrm{MS}+2 \mathrm{mg} \mathrm{L}^{-1} \mathrm{BA}+0.2 \mathrm{mg} \mathrm{L}^{-1} \mathrm{NAA}-$ supplemented media. Zhang and Jia (2014) reported the greatest shoot regeneration (88.91\%) of Lily (cv. Siberia) in MS $+1.07 \mu \mathrm{M} \mathrm{NAA}+4.44 \mu \mathrm{M}$ BA-supplemented media. Çakmak et al. (2016) worked with bulblet explants taken from in vitro-developed Fritillaria persica seedlings and obtained the maximum bulblet regeneration ratio and number of bulblets per explant from $2.0 \mathrm{mg} \mathrm{L}^{-1} \mathrm{TDZ}$-supplemented MS medium. In another study, maximum number of shoots (13.2 shoots) of bulblet pieces of Scilla hyacinthina was obtained from $2 \mathrm{mg} \mathrm{L}^{-1} \mathrm{TDZ}$-supplemented MS medium (Kamaleswari et al., 2016). Complying with the findings of the above-mentioned reports (Haibin and Jiajun, 2006; Yang et al., 2010; Sun and Jin, 2011; Zhang and Jia, 2014; Çakmak et al., 2016; Kamaleswari et al., 2016), in the second and third set of my experiments (Table 3 and 4), bulblet and shoot regeneration were achieved from in vitro-developed bulblet segments at varying ratios based on PGR combinations.

In previous in vitro propagation studies conducted with different species, more successful bulblet and shoot regeneration were generally achieved in BA + NAA (Haibin and Jiajun, 2006; Yang et al., 2010; Sun and Jin, 2011; Zhang and Jia, 2014; Razib et al., 2016), BAP + NAA (Tang et al., 2009; Choudhary et al., 2011), only BAP, (Nurashikin et al., 2010; Jakhar et al., 2012; Kamaleswari et al., 2016; Pandey, 2016) or TDZcontaining (Çakmak et al., 2016; Kamaleswari et al., 2016) MS media. Generally, in the second and third set of my experiments, $0.5 \mathrm{mg} \mathrm{L}^{-1} \mathrm{BAP}$-containing MS media and TDZ + NAA combinations yielded more successful bulblet and shoot formations (Table 3 and 4). 


\section{Conclusions}

This study is the first comprehensive report worldwide about the in vitro propagation of E. spectabilis. In the present study, bulblet and shoot regeneration from in vitro-developed hypocotyl explants and bulblet segments were investigated in several PGR combinations of MS media. The most successful outcomes in terms of bulblet and shoot formation were achieved in only BAP $\left(0.5 \mathrm{mg} \mathrm{L}^{-1}\right)$-containing and in TDZ $\left(0.5 \mathrm{mg} \mathrm{L}^{-1}\right)+$ NAA ( 0.5 and $\left.1.0 \mathrm{mg} \mathrm{L}^{-1}\right)$ combinations of MS media. In further studies of in vitro propagation of this species, besides TDZ + NAA combinations, BAP + NAA combinations could also be experimented with, bulb size could be increased, and a protocol for rooting the resultant bulblets and/or shoots could be developed.

\section{Acknowledgements}

The author wishes to thank Van Yüzüncü Yll University, Scientific Research Projects Department for the financial support (Project No: FBA-2018-6908).

\section{Conflict of Interests}

The authors declare that there are no conflicts of interest related to this article.

\section{References}

Abdul Baki AA, Anderson JD (1973). Vigor determination in soybean by multiple criteria. Crop Science 13:630-633. https://doi.org/10.2135/cropsci1973.0011183X001300060013x

Abubaker SR, Hidayat HJ (2015). Anti tumor potential of Local Aslerk (Eremurus spectabilis) leaf extracts by HPLC and applying on cancer cell lines in vitro. Iraqi Journal of Cancer and Medical Genetics 8(2):123-128.

Ahmad I, Dole JM, Schiappacasse F, Saleem M, Manzano E (2014). Optimal postharvest handling protocols for cut 'Line Dance' and 'Tap Dance' Eremurus inflorescences. Scientia Horticulturae 179:212-220. https://doi.org/10.1016/j.scienta.2014.09.031

Akdağ Ş (2019). Different combination treatments to improve germination and emergence performance on seeds of Eremurus spectabilis M. Bieb. M.Sc. Dissertation, University of Van Yüzüncü Yıl (in Turkish).

Ault JR, Siqueira SS (2008). Morphogenetic response of Lilium michiganense to four auxin-type plant growth regulators in vitro. Hortscience 43(6):1922-1924. https://doi.org/10.21273/HORTSCI.43.6.1922

Baskaran P, Kumari A, Naidoo D, Staden JV (2015). In vitro propagation and biochemical changes in Aloe pruinosa. Industrial Crops and Products 77:51-58. https://doi.org/10.1016/j.indcrop.2015.08.036

Baytop T (1996). Türkiye'de Bitkiler ile Tedavi. I.U. Yayinlari No: 3255, Eczacilik Fak 40:444 (in Turkish)

Choudhary AK, Ray AK, Jha S, Mishra IN (2011). Callus formation, shoot initiation and in vitro culture of Aloe vera. Biotechnology, Bioinformatics and Bioengineering 1(4):551-553.

Çakmak D, Karaoğlu C, Aasim M, Sancak C, Özcan S (2016). Advancement in protocol for in vitro seed germination, regeneration, bulblet maturation, and acclimatization of Fritillaria persica. Turkish Journal of Biology 40:878888. https://doi.org/10.3906/biy-1510-18

Dashti M, Tavakoli H, Zarif Ketabi H, Paryab A (2005). Ecological requirements of plant of Eremurus (E. spectabilis M.B.) in Khorasan province. Iranian Journal of Range and Desert Research 12(2):153-165.

Eghtedarnejad N, Mansouri HR (2016). Building wooden panels glued with a combination of natural adhesive of tannin/Eremurus root (syrysh). European Journal of Wood and Wood Products 74:269-272. https://doi.org/10.1007/s00107-015-0994-x 
Gamborg OL, Miller RA, Ojima K (1968). Nutrient requirements of suspension cultures of soybean root cells. Experimental Cell Research 60:151-158. https://doi.org/10.1016/0014-4827(68)90403-5

Güngör F (2002). Investigation on the morphological, biological characteristics and cultivation possibilities of Eremurus spectabilis (Bieb.) Fedtsch, Prangos ferulacea (L.) Lindl. and Hippomarathrum microcarpum (Bieb.) as growing wildly. Ph.D. Dissertation, University of Atatürk (in Turkish).

Haibin G, Jiajun L (2006). The bulb scale and bulblet culture in vitro of Lilium lancifolium Thunb. Chinese Agricultural Science Bulletin 2006-02.

Heshmatol Vaezin SM, Ghanbari S, Tavili A (2010). Income of Eremurus (E. olgae) and forage production in the Khazangah rangelands of Makoo. Journal of Range and Watershed Management (Iranian Journal of Natural Resources) 63(2):183-195.

Jakhar ML, Gurjar YR, Choudhary MR, Kakralya BL (2012). Regeneration in callus cultures of Ghritkumari (Aloe barbadensis Mill.). Journal of Plant Science and Research 28(1):131-136.

Kamaleswari K, Nandagopalan V, Lakshmi Prabha A (2016). Effects of plant growth regulators on in-vitro regeneration of a potential medicinal plant - Scilla hyacinthina (Roth.) J.F. Macbr. Journal of Applied Biology \& Biotechnology 4(01):043-046. https://doi.org/10.7324/JABB.2016.40108

Kamenetsky R, Akhmetova M (1994). Floral development of Eremurus altaicus (Liliaceae). Israel Journal of Plant Sciences 42(3):227-233. https://doi.org/10.1080/07929978.1994.10676575

Keskiner K (2017). Investigations on applications of breaking seed dormancy in grown wild Eremurus spectabilis M.Bieb. M.Sc. Dissertation, University of Van Yüzüncü Yll (in Turkish).

Keskiner K, Tuncer B (2019). Dormancy breaking treatments for wild Eremurus spectabilis M.Bieb seeds. Fresenius Environmental Bulletin 28(2A):1167-1173.

Matthews, WA (1986). Eremurus. Flora of Turkey and the East Aegean Island. 8:86-87.

Molsaghi M, Moieni A, Kahrizi D (2014). Efficient protocol for rapid Aloe vera micropropagation. Pharmaceutical Biology 52(6):735-739. https://doi.org/10.3109/13880209.2013.868494

Murashige T, Skoog F (1962). A revised medium for rapid growth and bioassays with tobacco tissue cultures. Physiologia Plantarum 15:473-497. https://doi.org/10.1111/j.1399-3054.1962.tb08052.x

Murillo-Amador B, López-Aguilar R, Kaya C, Larrinaga Mayoral J, Flores-Hernández A (2002). Comparative effects of $\mathrm{NaCl}$ and polyethylene glycol on germination, emergence and seedling growth of cowpea. Journal of Agronomy and Crop Science 188:235-247. https://doi.org/10.1046/j.1439-037X.2002.00563.x

Nurashikin K, Mihdzar Abdul K, Nur Ashikin Psyquay A, Ashraf F (2010). Rapid multiplication of Safed musli (Chlorophytum borivilianum) through shoot proliferation. African Journal of Biotechnology 9(29):4595-4600.

Pandey A (2016). Research on in-vitro clonal multiplication protocol in various cultivars of Chlorophytum. TechChronicle 1(4):32-42.

Pourfarzad A, Najafi MBH, Khodaparast MHH, Khayyat MH, Malekpour A (2014). Fractionation of (Eremurus spectabilis) fructans by ethanol: Box-Behnken design and principal component analysis. Carbohydrate Polymers 106:374-383. https://doi.org/10.1016/j.carbpol.2014.01.048

Rahmanpour A, Majd A, Chalabian F (2005). Effects of gibberellic and citric acid on germination percentage, speed of germination and seed vigor of (Eremurus spectabilis M.B). Iranian Journal of Rangelands and Forests Plant Breeding and Genetic Research 131(19):53-65.

Rahmanpour A, Majd A, Chalabian F (2007). The effect of hormones and mechanical treatments on seed germination of Eremurus olgae Regel. Iranian Journal of Medicinal and Aromatic Plants 23:1(35):111-120.

Razib MA, Mamun ANK., Kabir MH, Al Din SMS, Hossain ME, Firoz Alam M (2016). High frequency in vitro propagation of Aloe vera L. through shoot tip culture. International Journal of Applied Biology and Pharmaceutical Technology 7(4):28-32. http://dx.doi.org/10.21276/ijabpt

Schiappacasse F, Szigeti JC, Manzano E, Kamenetsky R (2013). Eremurus as a new cut flower crop in aysen, chile: introduction from the Northern hemisphere. Acta Horticulturae 1002:115-121. https://doi.org/10.17660/ActaHortic.2013.1002.13

Sharma S, Sharma D, Kanwar K (2015). Technology refinement for micropropagated Aloe vera L.: a miracle plant. Research in Plant Biology 5(4):1-10. 
Schenk RU, Hildebrandt AC (1972). Medium and techniques for induction and growth of monocotyledonous and dicotyledonous plant cell cultures. Canadian Journal of Botany 50(1):199-204. https://doi.org/10.1139/b72-026

Suh SY, Baskar TB, Kim HH, Al-Dhabi NA, Park SU (2015). Ethylene inhibitors promote shoot organogenesis of Aloe arborescens Miller. South Indian Journal of Biological Sciences 1(1):43-46.

Sun L, Jin L (2011). Studies on the in vitro rapid propagation of Lilium X Longliflorum. Liaoning Agricultural Science 2011-06.

Tang D, Wang Y, Xu J, Li W, Tian G, Tang K (2009). Adventitious shoot induction and plant regeneration from leaf explants of Lilium longiflorum Thunb. Propagation of Ornamental Plants 9(2):84-89.

Tosun M, Ercişli S, Ozer H, Turan M, Taşkın P, Öztürk E, Padem H, Kılıçgün H (2012). Chemical composition and antioxidant activity of foxtail lily (Eremurus spectabilis). Acta Scientiarum Polonorum Hortorum Cultus 11(3):145-153.

Tuncer B (2017). Investigation of the in vitro regeneration of some medical and aromatic wild plant species. Applied Ecology and Environmental Research 15(4):905-914. http://dx.doi.org/10.15666/aeer/1504_905914

Tuncer B (2018). Identification of wild plants which as vegetable consumed in Van province in Turkey. In: Proceedings of the $3^{\text {rd }}$ International Conference on Engineering Technology and Applied Sciences. Skopje, Macedonia pp 79-85.

Tuzcu Z, Koclar G, Agca CA, Aykutoglu G, Dervisoglu G, Tartik M, ... Sahin K (2017). Antioxidant, antimicrobial and anticancer effects of different extracts from wild edible plant Eremurus spectabilis leaves and roots. International Journal of Clinical Experimental Medicine 10(3):4787-4797.

Tuzlacı E (1985). The genus Eremurus (Liliaceae) in Turkey. Journal of Pharmacy of University of Marmara 1(1-2):91100.

Tuzlacı E (1987). Türkiye' nin çiriş otları (II): Asphodeline, Asphodelus, Eremurus ve Anthericum cinsleri üzerinde morfolojik karşılaştırmalar. Journal of Pharmacy of University of Marmara 3(1):19-26 (in Turkish).

Tuzlacı E, Doğan A (2010). Turkish folk medicinal plants, IX: Ovacık (Tunceli). Marmara Pharmaceutical Journal 14:136-143.

Wendelbo P (1982). Flora Iranica. In: Rechinger KH (ed). Asphodeloideae: Asphodelus, Asphodeline \& Eremurus, Graz, Austuria 151:3-31.

Wendelbo P (1982). Asphodeloideae: Asphodelus, Asphodeline \& Eremerus. In: Flora Iranica151:3-31.

White PR (1943). Nutrient deficiency studies and improved inorganic nutrients for cultivation of excised tomato roots. Growth 7:53-65.

Yang W, Zhang O, Pan H, Sun M (2010). In vitro regeneration of Lilium tsingtauense Gilg. and analysis of genetic variability in micropropagated plants using RAPD and ISSR techniques. Propagation of Ornamental Plants 10(2):59-66.

Zhang M, Jia G (2014). The effects of sucrose concentration and light condition on lily's bulblet-in-tube production and inclusion content. Pakistan Journal of Botany 46(1):307-315.

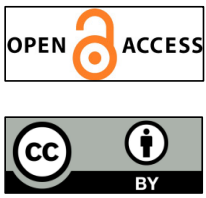

The journal offers free, immediate, and unrestricted access to peer-reviewed research and scholarly work. Users are allowed to read, download, copy, distribute, print, search, or link to the full texts of the articles, or use them for any other lawful purpose, without asking prior permission from the publisher or the author.

License - Articles published in Notulae Botanicae Horti Agrobotanici Cluj-Napoca are Open-Access, distributed under the terms and conditions of the Creative Commons Attribution (CC BY 4.0) License. (c) Articles by the authors; UASVM, Cluj-Napoca, Romania. The journal allows the author(s) to hold the copyright/to retain publishing rights without restriction. 